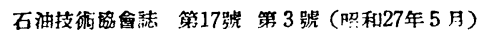

JOURNAL OF THE JAPANESE ASSOCIATION OF PETROLEUM TECHNOLOGISTS

VOL. 17, NO.3 (May, 1952)

\title{
天塩國中川郡美深町西方の地質予察
}

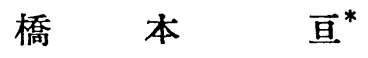

(昭和27年 4 月 9 日受理)

\section{A Geologic Reconnaissance of the Region West to Bifuka-ma- chi, Nakagawa-gun, Teshio Province, Hokkaido.}

By Wataru Hashimoto

This short article reffered to the results of a short reconnaissance work in the above mentioned region. Formerly, agglomerate found in this region was considered to be distributed on the Tertiary formation unconformablly. It was ascertained that the sa: $d$ agglomerate is interbedded in the Tertiary formation containing several lignite seams in its upper par $\iota$ and forms a large anticline elongated nearly longitudinally. It shows the present state of the progress of the geological survey in Hokkaido except the famous mineral lands that such a long anticline has never been found until today, though the area $\mathrm{i}_{\mathrm{s}}$ very near to a well communicated fartile land in the northern central Hokkaido.

The sedimentary formation exposed in this region is subdivided into two parts; the Kawanishi formation, the upper, and the Urubeshi formation, the lower which in $t$ arn is subdivided into two members, those are, the Hutamatabashi Agglomerate and the Tamagawa Andesitic Sandstone in descending order. The Kawanishi formation mainly consists of sandstone and conglomerate and contains several lignite seams in its middle part.

There is no oil indication has been known yet in this region but a spring of mineral water with sulphide order is met with in the axial part of the anticline at the upper stream of the Byoho-no-sawa.

筆者はここ数年来, 或はP E A C の $1 / 20$ 万北海道地資図の編輯, 或は北海道総合開

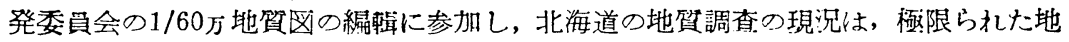
域, 例之は茂田, 沙田, 金属鉱山成は非金属鉱山周辺とかには精度の高い調查が行わ れているにも拘らず，一般には概査すら行われていない処の多い事を感じて来た。そ こで本篇のよ5な誠に嘪弱な予察報告でも何かの御役に立つ事を願つて, 敢えて発表 する次第でまりをす。

\footnotetext{
* 橋本地筫調查所所長
} 
小文に述べんとする処は，従来第三紀層の上にある若い集熄岩と考之られて来たる

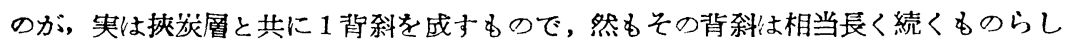
い事と, その地層がここの西方に当る朱料内方面で, 滝川㬝或は稚内硬䓄頁岩層に対 比されて来た地周に近似である事と，この樣な事が比較的交通の便利な処にあり乍ら 今まで気付かれずにあつたと云り点である。

美梁町 ${ }^{*}$ は宗谷本䅫で旭川市の北方約75籸の名寄町を中心とする天塩川凹地带1)の 中にあつて, 名寄酒との䦥には丘陵地があつてこの凹地带を南北に分けている。名寄 町か、らは北方 20 数籸に当り夏季はバスる通じている。

附近の地筫は岡村要蔵2゙が天㙁川はその支流のウルベシ川に沿つて予察旅行をして いるに過ざない。

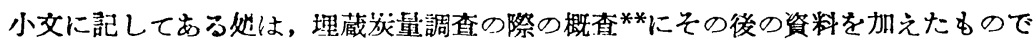

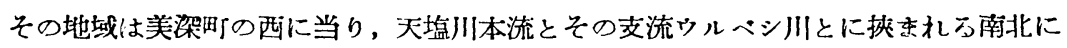
長い山地を, 北はウルベシ川の横谷となつている処から南は智恵交村の北部に至る間 である。

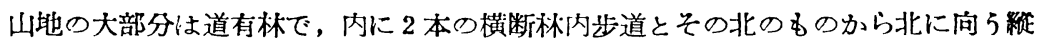
走步道の他に小さなるのか若干あつて, 天塩川沿い道路とウルベシ川沿いの道を結ん でいる。

分水筫は山地の西に偏し, 北方で $250 \mathrm{~m}$, 南方で $500 \mathrm{~m}$ 程の高さで南北に連る。これ と相対峙して東侧にも同じよ5に平均 $350 \mathrm{~m}$ の山頁の領が南北に連るのだが，この方 は横谷に切られている。ウルベシ川は下流で横谷を作つて山地の棈造を良く示してい、 る。

分水領の西はウルベシ川の中流部に向つて僅かにホッグパッグ地形を示すのみで, 大体平均した傾斜を示す。その傾科は北方程急で南下する程緩くなつていて，この部 分を復成する地層の傾斜を反映している。

分水箕に対峙する東の敛の東側には何処かの平坦面が見られ，その内，下の 3 段は 明かに樂層を頂く。

$1 / 5$ 万の地形四には，北海道の他の場所です良く見られるよらな沢の形の誤りがあ る。特に美梁苂坑の沢から苗围の沢に至る間に甚しい。 この山地を掅成する地層け次の如く分類される。即ち，

第四紀堆程物河休砂溫 段丘堆䅡物

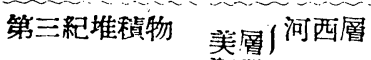

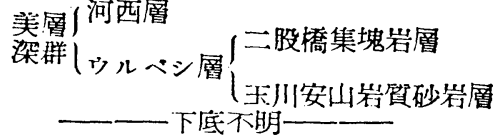

* ビウカと云わんていたが最近はビフカと云うようである。

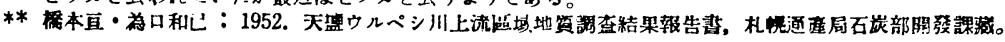


北海道天塩国中川郡美梁町西方川地地筫予察図

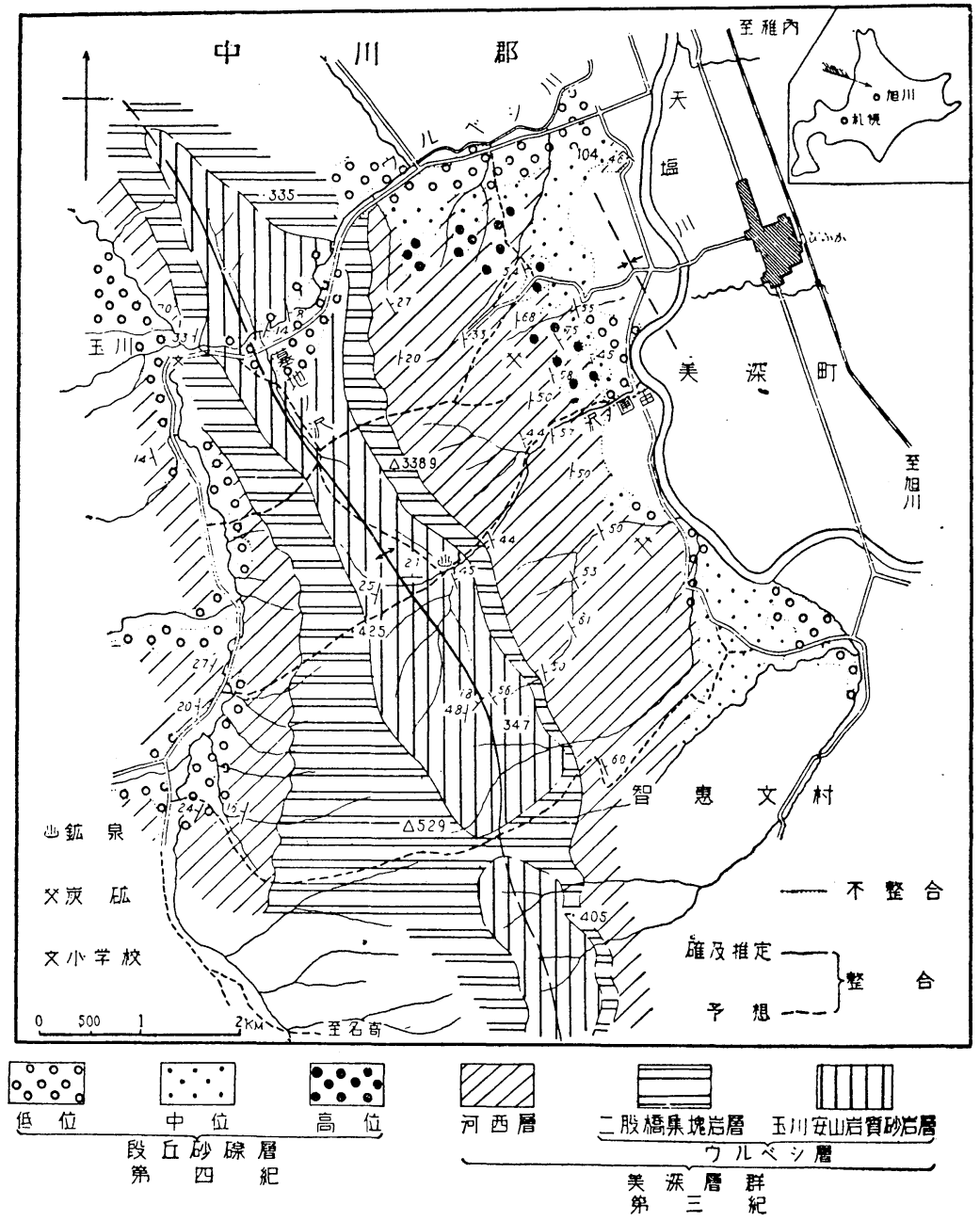

本域内に発達する第三系は, その棈造が大きな 1 つの背斜をする為に下底を露比し ていない。

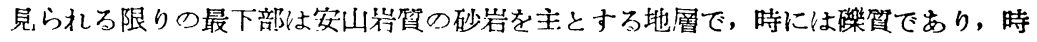

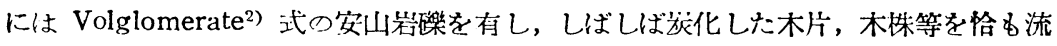
木として沈䅡させたかのよ5な座状において念有する。最す良い露Hはウルベシ川が 横谷を作り東流する部分の西僛で, 王川部落の墓地の沢合流点附近に見られる他に心

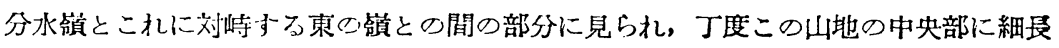
く南北に分布するのである。 
この地㐿は安山岩筫集塊岩に移化すろ。時にこの㬝準には安山岩の熔岩と思われる

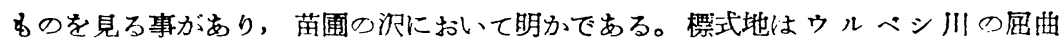
点，玉川部落の二股橋であつて，そこでは，他に比して厚さが薄くなつているが，分 水㯋の西側では南に行く程㫗くなつている。

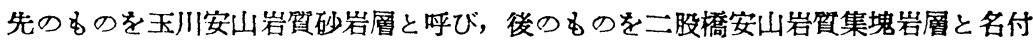
け、この 2 者を一括してウルベシ層と呼ぶ。

ウルベシ層は集塊岩風の上につく若干の安山岩質砂岩部を過て，䂺岩を主とする地 層に整合的に移化する。その地周を河西㬝と名付ける。

河西㬝の下部はクルミ〜ポテト大の古生㬝岩石の碟を主とする磁岩で，流木の炭化 又は硅化したものを稀に有する。

中部は軟筫の砂岩を主とし頁岩を伴 5 地㬝で，時に細か、酻層むある。側方变化に 富む地層で 2 尺内外の亜茂層を数枚介在寸る。そ机等の内には稼行可能と見られるる

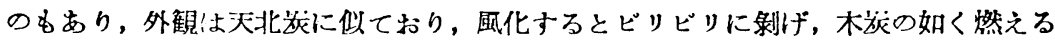
。発熱量は 4,300〜4.800 程である。上部は再び樂岩を主とした地阇となり，著しい 偽層を示す。

地層の厚さはもとより測定して見なかつたが，断面から察するにウルベシ周下部が $400 \mathrm{~m}+$, 上部の安山岩賀集塊岩が 100 200m 程で東南方ではもつと厚い上5に見受 けられる。河西層は $2,000 \mathrm{~m}$ 近くある樣だ。

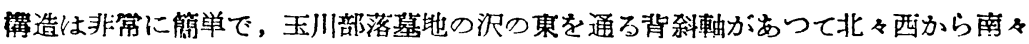
果に向い，北は恩根内村に，南は智患交村を過て名俞町市街地の西方に達す万らしい 事が，二股獢集塊岩層の作る地形から容易に推察される。筆者の見た処では明かに智 恵文村まで追跡焦来た。

一方ウルベシ川の西に汢この背斜軸の西に併走する。向斜部が認められ，その南限 は，ほぼウルベシ川の南端附近にあるらしいと年想される。その他東側にも亦併行す る背科が天塩川の下に存在するらしい事が，美梁橋北々西約 1 籸つ崖から祭せられ る。

本地域内において油徴は発見しなかつたが, 鉣泉俚苗國の㳄の上流, 背科朝部附近 に見られた。そこでは鉄管が打込まれており，高さ $1 \mathrm{~m}$ 半にも達しそらな処から硫化 水素臭を無する水が浚机て，附近に湯華を沈澱させている。

全層を通じて龙筫物や不完全な木の葉石しか発見估来なかつたので，時代の判定に 苦しむが，層序的に比較して見ると，当地の果北方に当る恩根内産炭地において鈴木 達夫")* が凝灰質砂岩層とした地㬝の中下部にも似ているし，文当地の西方に当る路

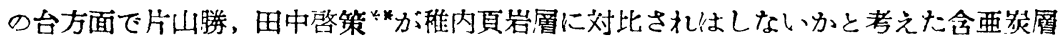
にも似ている。何れも集塊岩を下部に有する点は当地と共通であるが，両地ともに介

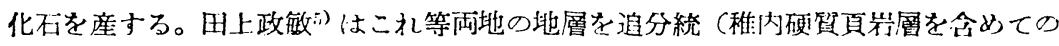

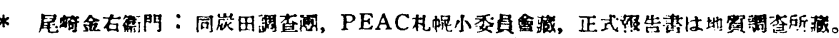

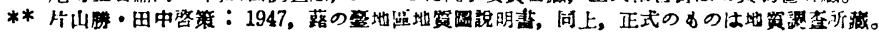


意味での) のあのと考えている。

路の台の南の朱鞠内に扣いては，この含要炭層は古丹別層の上に不整合に重るらし

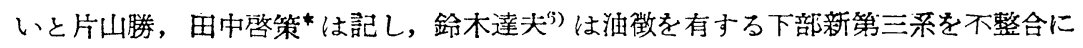

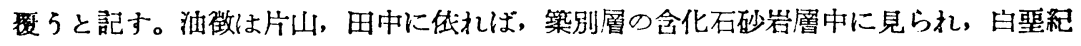
層に由来するるのと見做されている。

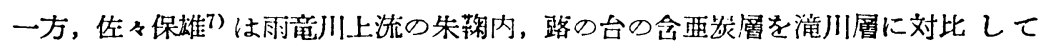
いる。然し，恵比島南方において曾て稼行されたよらな炭層が峠下層最下部にある 事8)を考えると，挈ろ海楱介化石の検討が望ましい。

\section{文䰚}

1）福地信世：1906,北海道の地体構造に関する一考察, 地学., XVI, pp. 843〜848

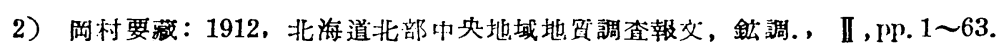
風村要藏：1912, 天塩川流域, 地学, X X IV,pp. 329〜334, 482〜189.

3) Alvir, A.D. 1929, A Geological Study of the Angat-Novaliche; Region, Fh ilıp. Jour. Sci,XL, pp. 359 415.

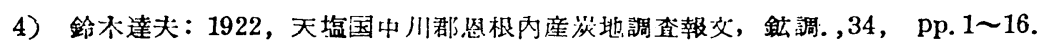

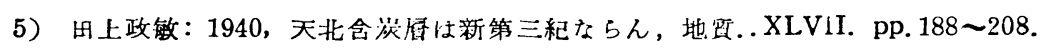

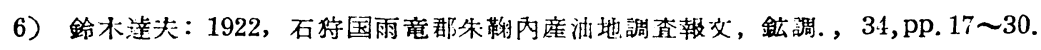

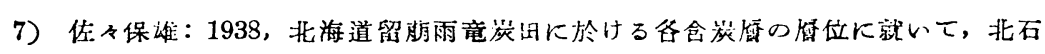
鉱㫰. , 291, pp. 1 6.

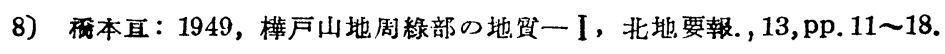

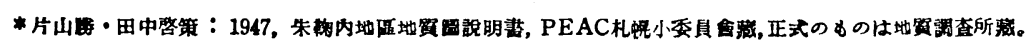

